\title{
Determination of Temporal Association Rules Pattern Using Apriori Algorithm
}

\author{
Shona Chayy Bilqisth* ${ }^{1}$, Khabib Mustofa ${ }^{2}$ \\ ${ }^{1}$ Master Program of Computer Science, FMIPA UGM, Yogyakarta, Indonesia \\ ${ }^{2}$ Department of Computer Science and Electronics, FMIPA UGM, Yogyakarta, Indonesia \\ e-mail: *11 shona.c@mail.ugm.ac.id, ${ }^{2}$ khabib@ugm.ac.id
}

\begin{abstract}
Abstrak
Sebuah swalayan harus mempunyai perencanaan bisnis yang baik agar dapat memenuhi keinginan pelanggan. Salah satu cara yang dapat dilakukan untuk memenuhi keinginan pelanggan adalah dengan mengetahui pola pembelian belanja yang dihasilkan dari pengolahan data transaksi penjualan. Pengolahan data menghasilkan informasi yang berkaitan dengan fungsi asosiasi antar item barang secara temporal. Fungsi Asosiasi merupakan salah satu fungsi dalam data mining.

Association rule adalah salah satu teknik data mining yang digunakan untuk menemukan pola kombinasi dari data transaksi. Algoritma Apriori dapat digunakan untuk menemukan association rules. Algoritma apriori digunakam untuk menemukan kandidat frequent itemset yang memenuhi support count. Frequent itemset yang memenuhi support count kemudian diproses menggunakan metode temporal association rules. Fungsi dari temporal association rules adalah sebagai pembatasan waktu dalam menampilkan hasil keluaran frequent itemsets maupun aturan asosiasi. Penelitian ini bertujuan untuk menghasilkan rulerule dari data transaksi, algoritma apriori digunakan untuk pembentukan temporal association rules. Hasil akhir penilitian ini mendapatkan rule-rule yang kuat yaitu rule-rule yang selalu muncul pada 3 tahun pada interval waktu tertentu dengan batasan support dan confidence, sehingga rule-rule dapat digunakan untuk rekomendasi perencanaan bisnis tata letak barang pada Swalayan Maharani Demak.
\end{abstract}

Kata kunci- penjualan, temporal association rules, apriori, data mining

\section{Abstract}

A supermarket must have good business plan in order to meet customer desires. One way that can be done to meet customer desires is to find out the pattern of shopping purchases resulting from processing sales transaction data. Data processing produces information related to the function of the association between items of goods temporarily. Association rules functions in data mining.

Association rule is one of the data mining techniques used to find patterns in combination of transaction data. Apriori algorithm can be used to find association rules. Apriori algorithm is used to find frequent itemset candidates who meet the support count. Frequent itemset that meets the support count is then processed using the temporal association rules method. The function of temporal association rules is as a time limitation in displaying the results of frequent itemsets and association rules. This study aims to produce rules from transaction data, apriori algorithm is used to form temporal association rules. The final results of this research are strong rules, they are rules that always appear in 3 years at certain time intervals with limitation on support and confidence, so that the rules can be used for business plan layout recommendations in Maharani Supermarket Demak.

Keywords—sales, temporal association rules, apriori, data mining

Received November 21 th 2019 ; Revised April 10 ${ }^{\text {th }}, 2020 ;$ Accepted April $29^{\text {th }}, 2020$ 


\section{INTRODUCTION}

Competition in the business world and advances in information technology are interrelated in the intense market competition to meet the increasingly high demands of customers. The company requires strategy and business intelligence to be able to meet customer desires[1]. So that technological advances are needed to develop business, one type of business that utilizes information technology is the retail business.

Competition in the business world, especially in the retail goods industry, requires developers to find an appropriate strategy in order to meet customer desires. One way that can be done is to find out the pattern of consumer shopping purchases so that appropriate measures can be applied [2]. The pattern of purchases of consumer purchases needs to be linked to the time dimension in order to get more complete information for preparing business plans.

Transaction data shows that most consumers at maharani supermarket buy two or more items. Based on interview with manager, consumers often experience difficulty to find other items that they want to buy because the layout of items far apart. It does not make them easier to choose the product they are looking for so that they often ask employees to find the items they are looking for. To overcome this, business planning is needed so that supermarkets can put goods according to the wishes of consumers. The supermarket manager is currently not able to make business plans as intended because there are problems with the supermarket. The problem that occurs is the unknown pattern of goods sold simultaneously and the unknown pattern of goods sold is related to time while the goods have been neatly arranged on a shelf based on the type and brand of the item.

To find the pattern of goods sold together in the sales data, the association method is used. The association method is one of the techniques in data mining that functions to find patterns of relationships between items that are associated each other. Apriori algorithm is used to look up association rules. In this study there are additional aspects of time to result association rules, this method serves as a time limitation in the appearance of frequent itemsets outputs and association rules [3].

Determination of the temporal association rule pattern using apriori algorithm is expected to be able to solve the problem, so it is known what items are often bought together at certain intervals to be made recommendations for business layout of the product layout at the supermarket.

\section{METHODS}

In conducting research there are several stages that must be done by the author, the stages are as follows:

1. Library Study

Before conducting research, the author first looks for references of knowledge related to research made from books, the internet and existing journals.

2. Field Research

In this stage, the writer does several things :

a. Data collection

In this stage, the authors collected data on 3-year sales transactions at supermarkets, sales transaction data in 2016, 2017, and 2018.

b. Observation

The author made direct observations on the Maharani Demak Supermarkets related to product layout on the supermarket.

c. Interview

The author conducted interviews directly to the manager.

3. Analysis

IJCCS Vol. 14, No. 2, April 2020 : $159-168$ 
In this stage, it explains the process of how to analyze product layout with the convenience of consumers finding the product sought at the supermarket.

4. Discussion of analysis based on the method used

Based on the analysis done, the writer helps the maharani supermarkets to be able to find out the pattern of purchasing goods simultaneously using the method chosen [3].

\subsection{Data Mining}

Data mining is an automated information search process that is useful in large data storage areas. Another understanding of data mining is an integral part of knowledge discovery in a database [4]. This research is one of the data mining functions of the association function, finding attributes that appear at a time. In the business world it is more commonly called shopping basket analysis (market basket analysis). The task of the association seeks to uncover the rules for measuring the relationship between two or more attributes[5].

The steps to solve research problem are carried out in the following five stages :

1. Preprocessing sales data. There are three steps to take, namely data selection, data cleaning, and data transformation.

2. Carrying out the candidate itemset process to obtain association rules. The process uses apriori algorithm.

3. Get a rule.

4. The rules that have been obtained are identified by adding date information on frequent itemset, the rules are sought again based on the time aspect.

5. Determine minimum support and minimum confidence, and generate rules from sales transaction data.

The stages in the temporal association rules process in the form of a scheme are shown in Figure 1.

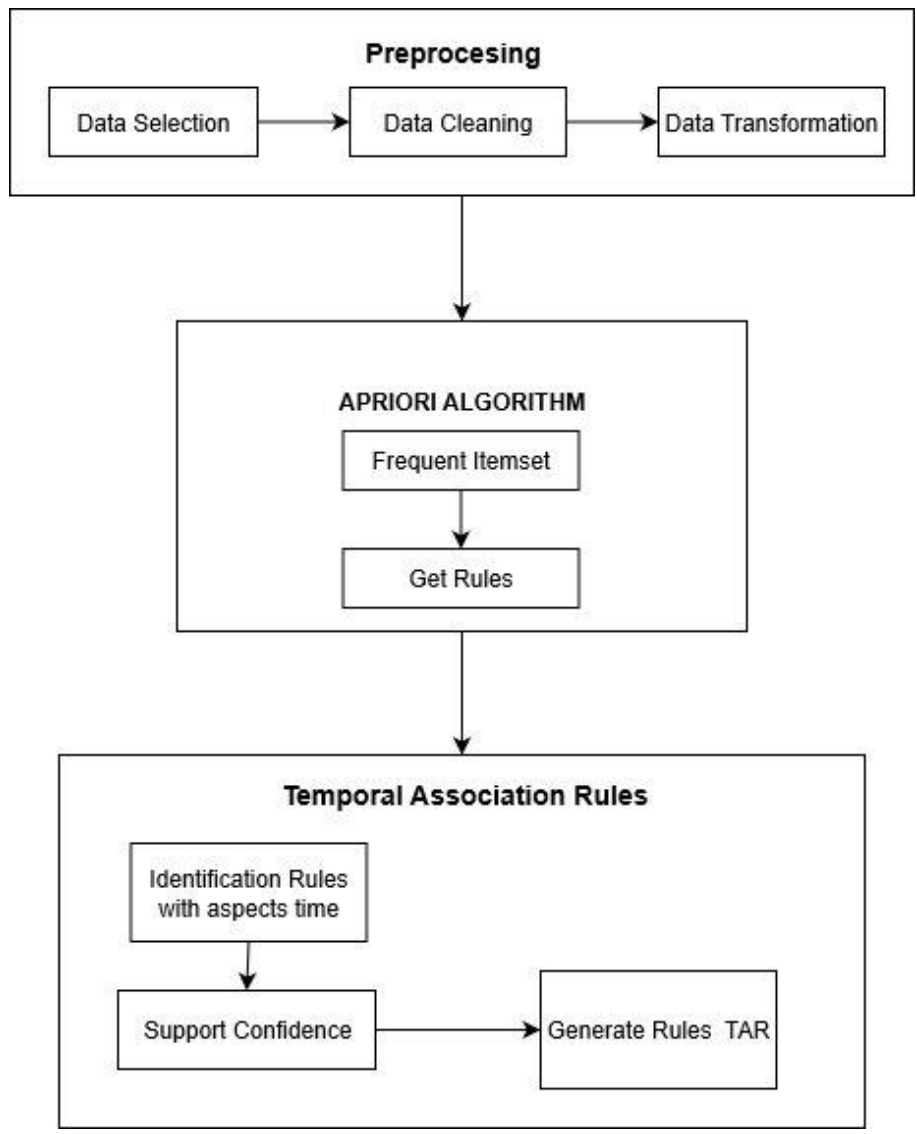

Figure 1 Stages in the process of temporal association rules 


\section{2 Data Preprocessing}

Preprocessing takes almost $60 \%$ of the data mining process starting from the aspect of time to the aspect of activity during overall data mining process. In this section there are three steps to be carried out, namely data selection, data cleaning, and data transformation.

1. Data Selection

Sales transaction data obtained in XLS format, there are several attribute records such as date, item code, transaction name, and selling price. From those several attributes, important attributes is selected. It is used for the process of data mining association rules with apriori algorithm for the formation of temporal association rules. These attributes are:, transaction date, item code, and item name.

2. Data Cleaning

At this stage, deletion is carried out for disturbing (noise) data. This stage is very important, because the results of the data mining process depend on the quality of the data chosen. In this case, the transaction data found unclear characters in the table of names of goods. Data is cleaned so that the data is ready to be used in the data mining process. Examples of things done at the data cleaning stage are removing the sign $(" ., \wedge .[, /)$ And changing capital letters into lowercase letters. Examples of cleaning up the names of goods in Table 1.

Table 1 Cleaning Results

\begin{tabular}{|l|l|l|}
\hline No & \multicolumn{1}{|c|}{ Product Name } & \multicolumn{1}{c|}{ Cleaning Results } \\
\hline 1 & "MITU SOFT WIP REFF & mitu soft wip reff \\
\hline 2 & LE MINERALE 600ML/24, & le minerale $600 \mathrm{ml}$ \\
\hline 3 & "SPRITE 1,5LT" & sprite $1,5 \mathrm{lt}$ \\
\hline 4 & Noodles AYM BWNG 2'S $/ 24$ & noodles aym bwng $2 \mathrm{~s}$ \\
\hline
\end{tabular}

3. Data Transformation

Data transformation is useful for structuring transaction data into a form that is easily processed by data mining. Some sales data still needs to be transformed. Like grouping types of goods into categories.

\section{3 Association Rules}

Association rules are rules that learn items or attributes that always appear together. The idea of association rules is to examine all if-then relationships between items and choose only the most likely (most likely) indicators of dependency relationships between items. Usually the term antecedent is used to represent the "if" part and consequent to represent the "then" part. In this analysis, antecedents and consequences are a group of items that do not have a joint relationship [6]. Association rules are if-then statements that help to show the probability of relationships between data items within large data sets in various types of databases. Association rule mining has a number of applications and is widely used to help discover sales correlations in transactional data or in medical data sets[7].

\section{4 Process of Finding Frequent Itemset}

There are two stages of seeking association rules, namely frequent itemset analysis and formation of association rules. Frequent itemset analysis look for combinations of items that meet the minimum requirements of a support value in an item's support value database obtained by the following formula. :

$$
\begin{aligned}
& \text { Support(A) }=\frac{\Sigma \text { Transacion } A}{\Sigma \text { Transaksi D }} \\
& \text { Support(A, B) }=\frac{\Sigma \text { Transaction Aand B }}{\Sigma \text { Transaction }}
\end{aligned}
$$

Formation of association rules by counting confidence is done by looking at associatoon rule A $\rightarrow \mathrm{B}$. confidence value from rule $\mathrm{A} \rightarrow \mathrm{B}$ is done by this following formula : 
Confidence $(A \rightarrow B)=\frac{\Sigma \text { Transaction } A \text { and } B}{\Sigma \text { Transaction } A}$

In order to get better understanding of this technique, the calculation steps are explained using a sample data of 8 sales transactions and a minimum support value is set at 3 (three). Table 1 shows the set of itemset $\mathrm{D}$ with the time attribute $\mathrm{T}$ which represents the date. There are 8 transactions involved that occur at a time that has a lifetime. Where $\mathrm{T}=2$ is the start time and $\mathrm{T}=8$ is the end time.

Table 2 List of Sales Transactions

\begin{tabular}{|c|l|c|}
\hline No & \multicolumn{1}{|c|}{ Transaction } & Time \\
\hline 1 & snack, milk, bread & 2 \\
\hline 2 & ketchup & 3 \\
\hline 3 & tea, parfume & 4 \\
\hline 4 & tea, bread, ketchup & 5 \\
\hline 5 & snack,milk & 6 \\
\hline 6 & tea, ketchup & 7 \\
\hline 7 & bread, ketchup & 8 \\
\hline 8 & snack,milk & 9 \\
\hline
\end{tabular}

Apriori algorithm is used to process $\mathrm{C} 1,1$-itemset candidate by scanning in table 2 , then items that meet the minimum support, L1, items in L1 are combined to get 2 -itemset $\mathrm{C} 2$ candidates. 2-itemset candidates who dont meet the support count are deleted, the minimum support value is set to 3 so items that appear below 3 will be deleted. Then L2 is used to search for 3-itemset candidates and so on until the items cannot be combined.

1. The frequent 1-itemset candidate process:

Table 3 Process candidate frequent 1 -itemset

\begin{tabular}{|c|c|c|c|c|c|c|}
\hline T & Database D & \multirow{9}{*}{$\begin{array}{l}\text { Scan D } \\
\rightarrow\end{array}$} & \multicolumn{2}{|c|}{$\mathrm{C} 1$} & \multicolumn{2}{|c|}{ L1 } \\
\hline 1 & snack, milk, bread & & Items & Count & Items & Count \\
\hline 2 & ketchup & & snack & 3 & snack & 3 \\
\hline 3 & tea, parfume & & milk & 3 & milk & 3 \\
\hline 4 & $\begin{array}{l}\text { tea, bread, } \\
\text { ketchup }\end{array}$ & & bread & 2 & ketchup & 4 \\
\hline 5 & snack,milk & & ketchup & 4 & tea & 3 \\
\hline 6 & tea, ketchup & & tea & 3 & & \\
\hline 7 & bread, ketchup & & parfume & 1 & & \\
\hline 8 & snack,milk & & & & & \\
\hline
\end{tabular}

2. Proses kandidat frequent 2-itemset :

Table 4 Process candidate frequent 2-itemset

\begin{tabular}{|c|c|c|c|c|c|c|}
\hline $\mathrm{T}$ & Database D & \multirow{9}{*}{$\underset{\rightarrow}{\operatorname{Scan} D}$} & \multicolumn{2}{|c|}{$\mathrm{C} 2$} & \multicolumn{2}{|c|}{ L2 } \\
\hline 1 & snack, milk, bread & & Items & Count & Items & Count \\
\hline 2 & ketchup & & snack, milk & 3 & snack, milk & 3 \\
\hline 3 & tea, parfume & & $\begin{array}{l}\text { snack, } \\
\text { ketchup }\end{array}$ & 0 & & \\
\hline 4 & $\begin{array}{l}\text { tea, bread, } \\
\text { ketchup }\end{array}$ & & snack, tea & 0 & & \\
\hline 5 & snack,milk & & $\begin{array}{l}\text { milk, } \\
\text { ketchup }\end{array}$ & 0 & & \\
\hline 6 & tea, ketchup & & $\begin{array}{l}\text { milk, } \\
\text { tea }\end{array}$ & 0 & & \\
\hline 7 & bread, ketchup & & ketchup, tea & 1 & & \\
\hline 8 & snack,milk & & & & & \\
\hline
\end{tabular}

\subsection{Process Temporal Association Rules}

After finding a frequent 2-itemset that meets the support count 3, which is \{ snack, milk\}. It explained that if you buy $\{$ snack $\}$ then also buy $\{$ milk $\}$. The association rule that has 
been obtained is then processed further by adding information about the time in the form of a transaction date, so that the resulting association rule already has an interval time. The process of determining the date of the transaction based on the date the first time shopping for [Ts] is considered as the smallest value and the last date of spending [Te] is considered as the largest value, which is in the span of lifetime [2]. Based on Table 4 in L2, the next step is to add transaction date information to each itemset, so that the mapping of each itemset that applies to the transaction date and the number of occurrences appears in Table 5.

Table 5 The results of mapping an itemset that has a lifetime

\begin{tabular}{|c|c|c|c|}
\hline No & Item & Transaction Time & Appearance Lifetime \\
\hline 1 & snack & $2,5,8$ & $(2,8)$ \\
\hline 2 & milk & $2,5,8$ & $(2,8)$ \\
\hline
\end{tabular}

After the number of times each item appeared and the transaction date are found, the next step, from the combination of rules that contain the itemset in table 4 , is to determine the minimum temporal support and confidence. The final temporal rules results are listed in Table 6.

Table 6 Results of temporal association rules

\begin{tabular}{|c|c|c|c|}
\hline No & \multicolumn{1}{|c|}{ TAR } & Minimum temporal support and & Prosentase \\
\hline 1 & $\{$ snack $\}=>\{$ milk $\}$ & Support $=3 / 8=0,38$ & Support $=38 \%$ \\
\hline 2 & $\{$ milk $=>\{$ snack $\}$ & Support $=3 / 8=0,38$ & Support $=38 \%$ \\
\hline
\end{tabular}

Based on the definition of association rule, defining the temporal association rule is done by adding temporal information in the form of transaction date. Adding the transaction date attribute as time will result in the resulting rules being temporal rules.

\section{RESULTS AND DISCUSSION}

To implement the data modeling, author used Python tools, the data used are sales transaction data at the Maharani Maharani supermarket. The number of sales data for 3 years ready for the data mining process is 429,832 records. From 3 years data, first year in 2016 the data was 126,590 records, second year in 2017, the data were 149,918 records and in 2018 the data were 153,324 records.This experiment is conducted by the author to find out strong rules, rules that always appear every year at certain time intervals.

The experiment was carried out with 2 schemes. The first scheme with a minimum suppport $\geq 0.07$ and minimum confidence $\geq 0.3$, the second scheme with a minimum suppport $\geq 0.02$ and minimum confidence $\geq 0.2$ with a time interval of 12 months, 6 months, 3 months, fasting month, christmas and new year. Here are the results of the tests carried out:

1. The results of the rules for 12 month minimum support 0.07 and minimum confidence $\geq 0.3$

Rules that always appear in 12 months in all data with minimum support 0.07 and minimum confidence $\geq 0.3$ as follows:

Table 7 rules 12 month minimum support $\geq 0.07$ and minimum confidence $\geq 0.3$

\begin{tabular}{|c|c|c|c|}
\hline No & interval_transaction & rule & temporal \\
\hline 1 & $01 / 01-31 / 12$ & milk $\Rightarrow>$ snack & ['01-01', '12-31'] \\
\hline
\end{tabular}

2. The results of the rules for 6 months minimum support 0.07 and minimum confidence $\geq 0.3$ Rules that always appear at the beginning of 6 months on all data are not generated because in 2017 data rules are not generated. While the rules that appear in the 2016 and 2018 data with minimum support $\geq 0.07$ and minimum confidence $\geq 0.3$ are as follows:

Table 8 rules 6 month minimum support $\geq 0.07$ and minimum confidence $\geq 0.3$

\begin{tabular}{|c|c|c|c|}
\hline No & interval_transaction & rule & temporal \\
\hline 1 & $01 / 01 / 2016-$ & milk $=>$ snack & ['2016-01-01', \\
\hline 2 & $01 / 01 / 2018-$ & milk => snack & ['2018-01-01', '2018- \\
\hline
\end{tabular}

The resulting rules are the same but there are differences when the rules appear in the 2016 data with the 2018 data. 
3. The results of the rules for 3 months minimum support 0.07 and minimum confidence $\geq 0.3$ Rules that always appear in 12 months in all data with minimum support support 0.07 and minimum confidence $\geq 0.3$ as follows:

Table 9 rules 3 month minimum support $\geq 0.07$ and minimum confidence $\geq 0.3$

\begin{tabular}{|c|c|c|c|}
\hline No & interval_transaction & rule & temporal \\
\hline 1 & $01 / 01-31 / 03$ & milk $=>$ snack & {$[$ [01-01', '03-31'] } \\
\hline
\end{tabular}

4. The results of the rules for fasting months minimum support 0.07 and minimum confidence $\geq 0.3$

In the fasting month, the consumption needs of the Muslim community can be said decreased. The need for comestible before the fasting month is arguably not the same as an ordinary day. The situation is actually strange, in every fasting month that spending every household that should be saved because of fasting (only eat twice a day, ie open and dawn) actually actually increases [8].

Rules that always appear in fasting months in all data with minimum support $\geq 0.02$ and minimum confidence $\geq 0.2$ as follows:

Table 10 rules fasting month minimum support $\geq 0.07$ and minimum confidence $\geq 0.3$

\begin{tabular}{|c|c|c|c|}
\hline No & interval_transaction & rule & temporal \\
\hline \multirow{2}{*}{1} & $17 / 05 / 2018-$ & \multirow{2}{*}{ milk $=>$ snack } & ['2018-05-17', \\
& $14 / 06 / 2018$ & & $2018-06-14 ']$ \\
\hline
\end{tabular}

5. The results of the rules for Christmas and New Year's months minimum support 0.07 and minimum confidence $\geq 0.3$

Christmas and New Year's Eve celebrations, where demand for consumer goods will increase at this momentum. This can be seen from the 3-month Price Expectation Index in the BI survey which showed an increase to 177.1 from 172.6 in the previous month [9].

Rules that always appear in fasting months in all data with minimum support $\geq 0.07$ and minimum confidence $\geq 0.3$ as follows:

Table 11 rules christmas month minimum support $\geq 0.07$ and minimum confidence $\geq 0.3$

\begin{tabular}{|c|c|c|c|}
\hline No & interval_transaction & rule & temporal \\
\hline \multirow{2}{*}{1} & $20 / 12 / 2017-$ & milk $=>$ snack & ['2017-12-20', \\
& $10 / 01 / 2018$ & & \\
& \multicolumn{2}{|c}{$2018-01-10 ']$} \\
\hline
\end{tabular}

6. The results of the rules for 12 month minimum support 0.02 and minimum confidence $\geq 0.2$ Rules that always appear in 12 months in all data with minimum support $\geq 0.02$ and minimum confidence $\geq 0.2$ as follows:

Table 12 month rules 12 month minimum support $\geq 0.02$ and minimum confidence $\geq 0.2$

\begin{tabular}{|c|c|c|c|}
\hline No & interval_transaction & rule & temporal \\
\hline 1 & \multirow{7}{*}{$01 / 01-31 / 12$} & ice cream $\Rightarrow>$ snack & ['01-01', '12-31'] \\
\hline 2 & & instant noodles $=>$ snack & ['01-01', '12-31'] \\
\hline 3 & & instant noodles $=>$ milk & ['01-01', '12-31'] \\
\hline 4 & & flavored drinks $=>$ snack & ['01-01', '12-31'] \\
\hline 5 & & flavored drinks $=>$ milk & ['01-01', '12-31'] \\
\hline 6 & & snack $=>$ milk & ['01-01', '12-31'] \\
\hline 7 & & milk $\Rightarrow$ snack & ['01-01', '12-31'] \\
\hline
\end{tabular}

7. The results of the rules for 6 month minimum support 0.02 and minimum confidence $\geq 0.2$ 
Rules that always appear in 6 months in all data with minimum support $\geq 0.02$ and minimum confidence $\geq 0.2$ as follows :

Table 13 month rules 6 month minimum support $\geq 0.02$ and minimum confidence $\geq 0.2$

\begin{tabular}{|c|c|c|c|}
\hline No & interval_transaction & rule & temporal \\
\hline 1 & \multirow{4}{*}{$\begin{array}{c}01 / 01-30 / 06 \\
(2016 \text { dan 2017) }\end{array}$} & instant noodles $=>$ snack & ['01-01', '06-30'] \\
\hline 2 & & flavored drinks $=>$ snack & ['01-01', '06-30'] \\
\hline 3 & & snack $\Rightarrow>$ milk & ['01-01', '06-30'] \\
\hline 4 & & milk $=>$ snack & ['01-01', '06-30'] \\
\hline 5 & \multirow{4}{*}{$\begin{array}{c}01 / 01-30 / 06 \\
2018\end{array}$} & Instant noodles $=>$ snack & ['01-01', '06-24'] \\
\hline 6 & & flavored drinks $=>$ snack & ['01-01', '06-24'] \\
\hline 7 & & snack $=>$ milk & ['01-01', '06-24'] \\
\hline 8 & & milk $=>$ snack & ['01-01', '06-24'] \\
\hline
\end{tabular}

8. The results of the rules for 3 month minimum support 0.02 and minimum confidence $\geq 0.2$ Rules that always appear in 3 months in all data with minimum support $\geq 0.02$ and minimum confidence $\geq 0.2$ as follows :

Table 14 month rules 6 month minimum support $\geq 0.02$ and minimum confidence $\geq 0.2$

\begin{tabular}{|c|c|c|c|}
\hline No & interval_transaction & rule & temporal \\
\hline 1 & \multirow{3}{*}{$01 / 01-31 / 03$} & instant noodles => snack & {$[$ ['01-01', '03-31'] } \\
\cline { 4 - 4 } 2 & flavored drinks => snack & {$[$ ['01-01', '03-31'] } \\
\cline { 3 - 4 } 3 & milk => snack & {$[$ ['01-01', '03-31'] } \\
\cline { 3 - 4 } 4 & & snack => milk & {$[$ ['01-01', '03-31'] } \\
\cline { 1 - 1 } & &
\end{tabular}

9. The results of the rules for fasting month minimum support 0.02 and minimum confidence $\geq$ 0.2

Rules that always appear in fasting months in all data with minimum support $\geq 0.02$ and minimum confidence $\geq 0.2$ as follows :

Table 15 month rules fasting month minimum support $\geq 0.02$

\begin{tabular}{|c|c|c|c|}
\hline No & interval transaction & rule & temporal \\
\hline 1 & \multirow{6}{*}{$17 / 05 / 2018-14 / 06 / 2018$} & Ice cream $=>$ snack & ['2018-05-17', '2018-06-14'] \\
\hline 2 & & sugar $\Rightarrow$ snack & ['2018-05-17', '2018-06-14'] \\
\hline 3 & & instant noodles $=>$ snack & ['2018-05-17', '2018-06-14'] \\
\hline 4 & & instant noodles $=>$ milk & ['2018-05-17', '2018-06-14'] \\
\hline 5 & & flavored drinks $=>$ snack & ['2018-05-17', '2018-06-14'] \\
\hline 6 & & flavored drinks $=>$ milk & ['2018-05-17', '2018-06-14'] \\
\hline 7 & \multirow[t]{5}{*}{$17 / 05 / 2018-14 / 06 / 2018$} & baby gear $=>$ milk & ['2018-05-17', '2018-06-14'] \\
\hline 8 & & snack $\Rightarrow>$ milk & ['2018-05-17', '2018-06-14'] \\
\hline 9 & & milk $\Rightarrow>$ snack & ['2018-05-17', '2018-06-14'] \\
\hline 10 & & tea $=>$ snack & ['2018-05-17', '2018-06-14'] \\
\hline 11 & & tea $=>$ susu & ['2018-05-17', '2018-06-14'] \\
\hline
\end{tabular}

4 rules that do not necessarily appear but in the event of fasting appear, namely sugar $=>$ snack, baby gear $=>$ milk, tea $=>$ snack, and tea $=>$ milk.

10. The results of the rules for Christmas and New Year's months minimum support 0.02 and minimum confidence $\geq 0.2$

Rules that always appear in fasting months in all data with minimum support $\geq 0.02$ and minimum confidence $\geq 0.2$ as follows: 
Table 16 month rules christmas and new year month minimum support $\geq 0.02$

\begin{tabular}{|c|c|c|c|}
\hline No & interval transaction & rule & temporal \\
\hline 1 & \multirow{7}{*}{$20 / 12 / 2017-10 / 01 / 2018$} & Mineral water $=>$ snack & ['2017-12-20', '2018-01-10'] \\
\hline 2 & & Ice cream $=>$ snack & ['2017-12-20', '2018-01-10'] \\
\hline 3 & & bread $=>$ snack & ['2017-12-20', '2018-01-10'] \\
\hline 4 & & instant noodles $=>$ snack & ['2017-12-20', '2018-01-10'] \\
\hline 5 & & instant noodles $=>$ milk & ['2017-12-20', '2018-01-10'] \\
\hline 6 & & flavored drinks $=>$ snack & ['2017-12-20', '2018-01-10'] \\
\hline 7 & & flavored drinks => milk & ['2017-12-20', '2018-01-10'] \\
\hline 8 & \multirow[t]{7}{*}{$20 / 12 / 2017-10 / 01 / 2018$} & nuget $=>$ snack & ['2017-12-20', '2018-01-10'] \\
\hline 9 & & baby gear $=>$ snack & ['2017-12-20', '2018-01-10'] \\
\hline 10 & & candy $=>$ snack & ['2017-12-20', '2018-01-10'] \\
\hline 11 & & bath soap $=>$ snack & ['2017-12-20', '2018-01-10'] \\
\hline 12 & & susu $=>$ snack & ['2017-12-20', '2018-01-10'] \\
\hline 13 & & snack $=>$ milk & ['2017-12-20', '2018-01-10'] \\
\hline 14 & & tea $=>$ snack & ['2017-12-20', '2018-01-10'] \\
\hline
\end{tabular}

Differences in the results of the temporal association rules occur in the month of the event [10]. There are 7 rules that never appear, but at the Christmas 2017 and 2018 new year events, mineral water $=>$ snack, cake $\Rightarrow>$ snack, nuget $=>$ snack, baby gear $\Rightarrow$ snack, candy $\Rightarrow$ snack, bath soap $==$ snack, and tea $=>$ snack. Thus, these 7 rules are important to be accommodated in the product layout business plan for the month of the Christmas and upcoming new year events.

\section{CONCLUSIONS}

1. Determination of temporal association rule patterns can be generated using apriori algorithm, obtained strong rules, rules that always appear with a period of 12 months and 6 months.

2. Rules that appear in the time interval of 12 months and 6 months in the data 2016,2017 , and 2018 show that the rule is strong so that it can be used as a recommendation to make business plan in maharani supermarket.

3. Business plan product placement in a supermarket can use a strong rule with 2 models, namely if you change the layout once in 12 months using the results of the 12-month interval, if you change the layout every 6 months using the results of 6-month interval, and, if you change the layout every 3 months using the results of 3-month interval. the layout for goods items that are not contained in the generated rule can use old pattern used by supermarkets like that.

\section{REFERENCES}

[1] V.N. Latifah, M.T. Furqon, and N. Santoso, "Implementasi Algoritme Modified-Apriori Untuk Menentukan Pola Penjualan Sebagai Strategi Penempatan Barang Dan Promo," Journal of Information Technology and Computer Science Development, vol. 2, no. 10, $2018 \quad$ [Online]. Available: http://j-ptiik.ub.ac.id/index.php/jptiik/article/view/2764/1051. [Accessed: 21-Nov-2019]

[2] R. Yanto and R. Khoiriah, "Implementasi Data Mining dengan Metode Algoritma Apriori dalam Menentukan Pola Pembelian Obat," CITEC (Creative Information Technology Journal), vol. 2, no. 2, 2015 [Online]. Available:https://pdfs.semanticscholar.org/9135/4235119ad862d3c69de94b0ca7992442 
7ed0.pdf. [Accessed: 18-Nov-2019]

[3] A. Maulani, "Discovering Temporal Association Rules Using Apriori Algorithm (Case Study : Toko Batik Diyan Solo)," Tesis, Program Pasca Sarjana Ilmu Komputer, Universitas Gajah Mada, 2015.

[4] F.A. Santuni, "Penerapan Algoritma Apriori Untuk Penentuan Tingkat Pesanan," Jurnal Mantik Penusa Journal In Information Systems, Vol. 2, No. 1, 2018 [Online]. Available: $\quad$ http://e-jurnal.pelitanusantara.ac.id/index.php /mantik/article/download/330/216. [Accessed: 18-Nov-2019]

[5] D.T Larose and C.D. Larose, "Discovering Knowledge In Data An Introduction to Data Mining”, Ed.2, New Jersey, Canada, 2014.

[6] E. Prasetyo, Data Mining - Processing Data into Information Using Matlab, Ed.1, Andi Offset, Yogyakarta : Deepublish, 2014.

[7] D.P. Larasati, M. Nasrun, and U.A Ahmad., "Analysis and Implementation of FP Groth Algorithm in Smart Aplication to Determine Market Basket Analysis on Retail Business (CaseStudy:PT.X)", Jurnal Telkom Bandung University, vol. 2, no. 1, 2015. [Online]. Available:

https://libraryeproceeding.telkomuniversity.ac.id/index.php/engineering/article/view/20 62/1949. [Accessed: 18-Nov-2019]

[8] A. Hidayat,"Budaya Konsumen Bulan Ramadan bagi Masyarakat Modern di Indonesia", Jurnal Institut Agama Islam Negeri Purwokerto, vol. 14, no. 2, 2016. [Online].Available: http://ejournal.iainpurwokerto.ac.id/index.php/ibda/article/view/684 [Accessed: 18-Nov-2019]

[9] A.N.K. Movanita.,"Survei BI: Konsumen Ekspektasi Tekanan Harga Naik di Akhir Tahun", 2018. [Online]. Available: https://ekonomi.kompas.com/read/2018/10/05/130107726/survei-bi-konsumenekspektasi-tekanan-harga-naik-di-akhir-tahun. [Accessed: 21-Nov-2019]

[10] A. Maulani, S. Hartati, and A. Musdholifah, "Pembentukan Temporal Association Rules Menggunakan Algoritma Apriori (Studi Kasus:Toko Batik Diyan Solo)", IJCCS (Indonesian J. Comput. Cybern. Syst., vol.10, no. 1, 2016 [Online]. Available: https://jurnal.ugm.ac.id/ijccs/article/view/11190/8430. [Accessed: 21-Nov-2019] 